\title{
Waste Bank Data Management Information System with Web-Based Telegram Bot Notification Feature at Mawar Garbage Bank
}

\author{
Rahmat Robi Waliyansyah (iD) ${ }^{*}$, Mega Novita (D) \\ 1,2 Department of Informatics, Universitas PGRI Semarang, Semarang 50125, Indonesia \\ *rahmat.robi.waliyansyah@upgris.ac.id (coresponden author) \\ novita@upgris.ac.id
}

Article history :

Received : 11 Aug 2021

Accepted : 16 Aug 2021

Available online : 05 Nov 2021

\section{ABSTRACT}

The Mawar Garbage Bank needs a waste bank data management information system with a Web-based Telegram Bot notification feature on the Garbage Bank. The goal is to provide convenience to the officers of the Mawar Garbage Bank to speed up the process of managing data and delivering information in an effective and efficient manner to customers. This research uses the waterfall method. By using a MySQL database, PHP programming language and Laravel Framework. As well as diagrams used for system modeling using the Unified Modeling Language (UML). With this system, it is hoped that it can make it easier to manage data and provide information about the waste bank which is useful for the Mawar Garbage Bank. This research will be tested using Black Box, White Box and User Acceptance Test (UAT). As for the notification using a telegram bot. The notification from the telegram bot aims to make it easier for customers to find information such as balances, savings flows, and cash withdrawals. From the black box test, you get 100\% results, which means that the system has met the design objectives, so this system is suitable for use. White box test results get $100 \%$ results with the resulting complexity is 2 which shows that it can meet the criteria for software engineering. The results of the user acceptance test (UAT) test get a 98\% result, which means that the software is acceptable and has met the requested needs.

Keywords : bot telegram, garbage bank, reminder.

This is an open access article under the CC-BY-SA license.

(i) (9)

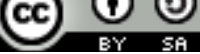




\section{INTRODUCTION}

The Waste Bank is a form of public awareness in overcoming waste management problems that are still emerging today. One form of this is by utilizing existing waste for recycling so that it has added value and reduces the volume of waste disposed of at the TPA (Deharja \& Permatasari, 2016). The Mawar Garbage Bank is a manifestation of community awareness in Jogoloyo Village in overcoming the problem of waste management. In this Mawar Garbage Bank, it is managed by retired civil servants in Jogoloyo Village. The purpose of the Mawar Garbage Bank is to manage and manage waste from its source. In addition, it is also used as a place to save household waste, as well as provide guidance to the community to sort, select and process existing waste into products that are useful and have a selling value so that they can help improve the economy of the surrounding community (Destiningrum \& Adrian, 2017). However, Mawar Garbage Bank still has several problems in managing information and data management which is still conventional using books. Therefore, in this study we collaborated with the management of the Mawar Garbage Bank to help solve the problems that exist in the Mawar Garbage Bank by creating an information system about the web-based waste bank.

In this study we used the waterfall method and for modeling the system using UML. The reason the author uses the web in this system is because every user who uses a web application will find it easy to access the information provided (Hidayat \& Muttaqin, 2018). Because web applications can be accessed using various devices and the operating system can adjust to various devices and operating systems (Maharani, 2017). In addition, it is also equipped with a telegram bot notification system which is useful for making it easier for customers to view information about the Mawar Garbage Bank. The ease of access provided by telegram which can run in almost all platforms makes it easy for users to build a notification system by utilizing the telegram bot facility provided with messages automatically (Maulayya et al., 2019). The use of the Telegram notification system at the Mawar Garbage Bank aims to provide useful information for Mawar Garbage Bank customers in order to create effective and efficient information.

The results of this study are expected to provide solutions to solve the problems that exist in the Mawar Garbage Bank and provide convenience for garbage bank officers and customers. With the existence of a waste bank data management information system with the WEB-based Telegram Bot notification feature at the Mawar Desa Jogoloyo Demak Waste Bank, it can provide information about the Mawar Garbage Bank and help make it easier to record and manage waste bank data (Okstania et al., 2019).

\section{RESEARCH METHOD}

The rapid development of communication technology with many emerging various sophisticated telecommunication or communication tools, such as telephone, cellular, television, radio, telegram, facsimile, and so on. As well as problems that occur in the community itself (Rifai \& Mustafidah, 2013). The problem in this research is that there is no Waste Bank information system at the Mawar Garbage Bank. This study aims to provide information about the Mawar Waste Bank and to help facilitate the recording and management of waste bank data. The framework of thinking used in this research is the waterfall method. To overcome waste management regarding the absence of a waste bank data management information system with a web-based telegram bot notification feature on the Mawar Waste Bank. With the Telegram Bot reminder, it is expected to be able to notify or as a notification to Rose Waste Bank customers. For this reason, the first step is analysis by observing the Mawar Waste Bank and collecting data. The second stage is design which includes system design: use cases, activity diagrams, sequence diagrams and class diagrams (Kusrini et al., 2019). The design of the database design uses a class diagram. Meanwhile, the method used is the waterfall method including preparation, design, implementation and testing. By using Telegram Bot-based modeling. Furthermore, the third stage of implementation using the MySQL database, the PHP programming language and the Laravel Framework. The last stage is the testing stage using the White Box, Blackbox and User Acceptance Test (UAT) testing methods (Salim et al., 2017).

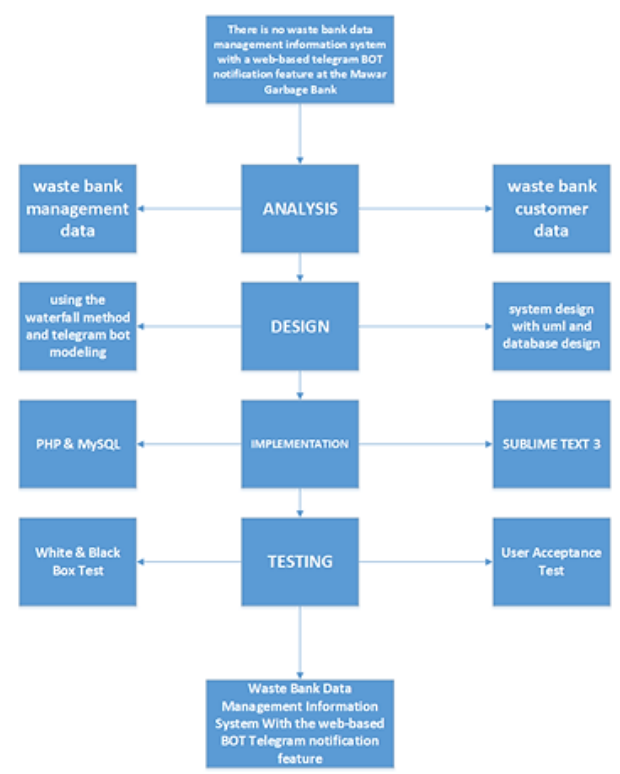

Fig. 1. Framework for development of a waste bank information system. 


\section{RESULT AND DISCUSSION}

The application development method used is the waterfall method, the following are the stages of application development based on the order of the methods used:

\subsection{System analysis}

\subsubsection{Current system analysis}

System analysis is an activity to identify and evaluate problems that occur in a system to be created. This system is designed to help Mawar Garbage Bank in managing waste in order to create a clean environment. For now, the Mawar Garbage Bank still uses a manual system, namely by using an accounting book which is used to record all transactions for the Mawar Waste Bank customers, so this is less effective and efficient. In analyzing the system to be created, the author will use the Unified Modelling Language (UML), which includes modelling use case diagrams, class diagrams, sequence diagrams, and activity diagrams (Parianthana et al., 2018).

\subsubsection{Analysis of system and user requirements}

The weakness of the system that runs at the Mawar Garbage Bank itself is that there is no awareness of the importance of managing waste into a rupiah value by saving through the waste itself. From these problems, we need a system that can help the community by utilizing and managing waste properly and making it easier to carry out transactions with customers. Yang user needs related to the system and all about the activities that users can do on the waste bank management information system with the Telegram Bot on the web-based rose waste bank (Priantoro \& Rapiyanta, 2016).

1) User: users can see what activities are being shared and the latest information from the chairman of the Mawar Garbage Bank;

2) Admin: can log in to manage data management information system waste bank data management with BOT Telegram at Mawar Garbage Bank.

\subsubsection{Analysis of software and hardware requirements}

Software Requirements : Windows 10 ultimate 64 bit operating system, XAMPP as a local server, MySQL databases, Web browsers such as Google chrome, Mozilla Firefox, Opera Web Browser or UC Browser, Notepad ++ as code text for writing programs, Sublime Text3 as a program aid from notepad++, Draw IO as a design system design.

Hardware Requirements: Minimum 4 GB RAM in system design, ASUS laptop with Intel (R) core (TM) i5-3110M processor with 32-bit Operating System type system

\subsubsection{Alternative systems are proposed}

From the existing problems, it can be suggested that the waste bank data management information system with the Telegram Bot notification feature on the Mawar Garbage Bank. can be an alternative to the effectiveness of the existing system.

\subsection{Design}

\subsubsection{Use case diagram}

Use Case Diagram is a model for the behavior of the information system to be made. Use Case describes an interaction between one or more actors with the information system to be created (Ramadhan, 2017). In this use case diagram, there are 3 actors, namely customers, officers, and administrators who must enter the login form first before being able to access the main menu form. Use case diagrams can be seen in Fig. 2 .

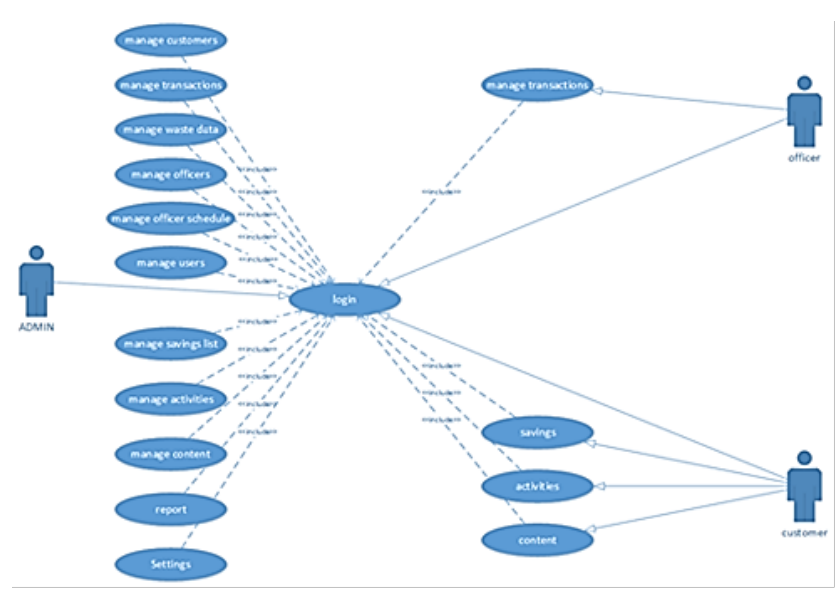

Fig. 2. Use case diagram.

\subsubsection{Class diagram}

Class is a specification that if instantiated will produce an object and is the core of object-oriented development and design. Class describes the state (attribute / property) of a system, as well as offering services to manipulate that state (method / function). The class has three main or main areas, namely names, attributes and methods. The class diagram is shown in Fig. 3.

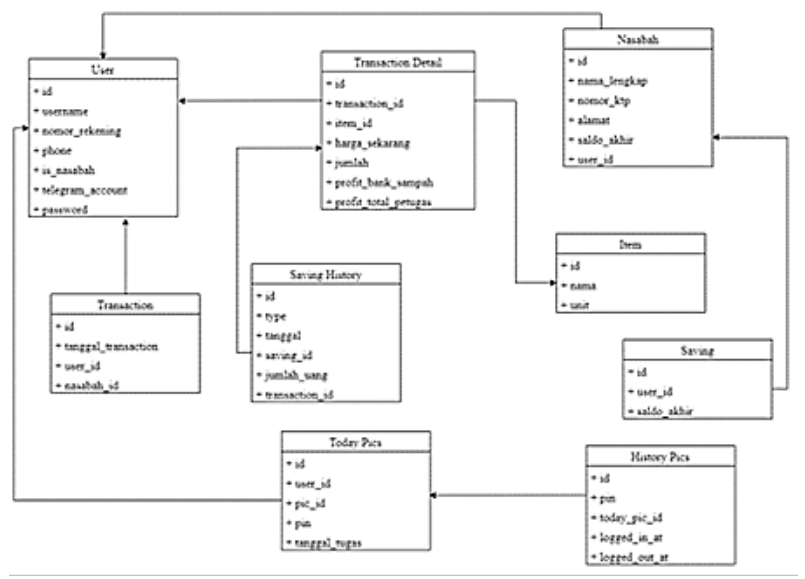

Fig. 3. Class diagram.

\subsection{Implementation}

\subsubsection{Add transaction menu page}

Fig. 4 on the add transaction page shows creating a new transaction for the customer. After making a transaction, show the transaction history as shown below. 


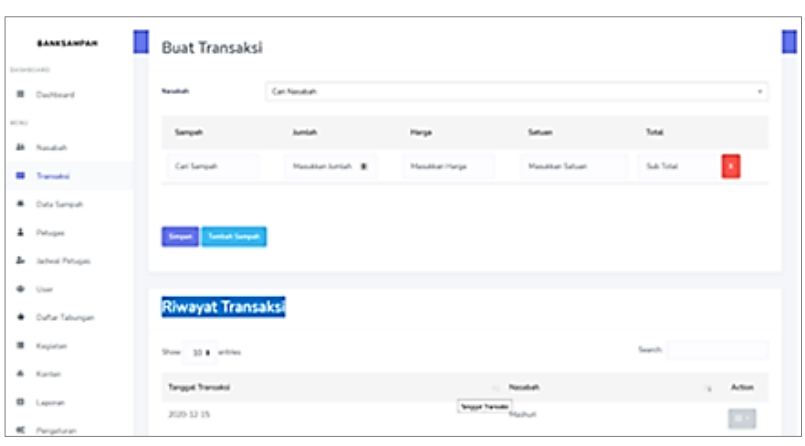

Fig. 4. Add transaction menu page.

\subsubsection{Menu savings page}

Fig. 5 on the details page of this savings list shows the customer's last balance and history when making transactions and withdrawing balances.

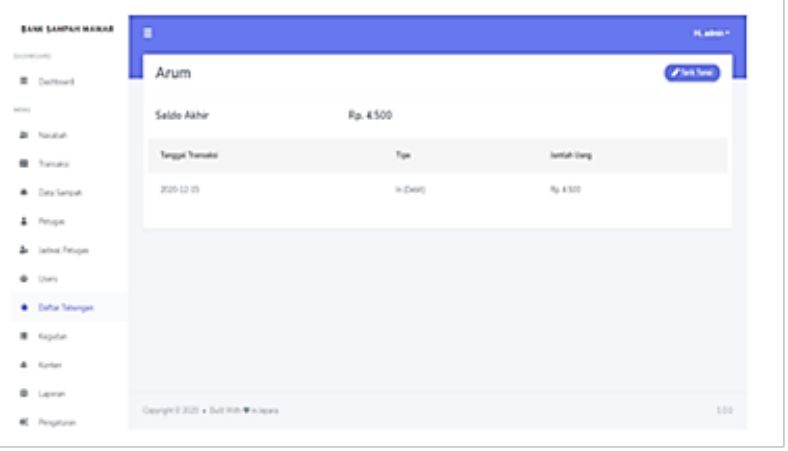

Fig. 5. Savings menu page.

\subsubsection{Telegram bot notification page}

The Fig. 6 on this page customers who have been added by the admin are given a temporary account number and password. The customer opens the telegram application and clicks start / start and the customer gets a notification like the image above.

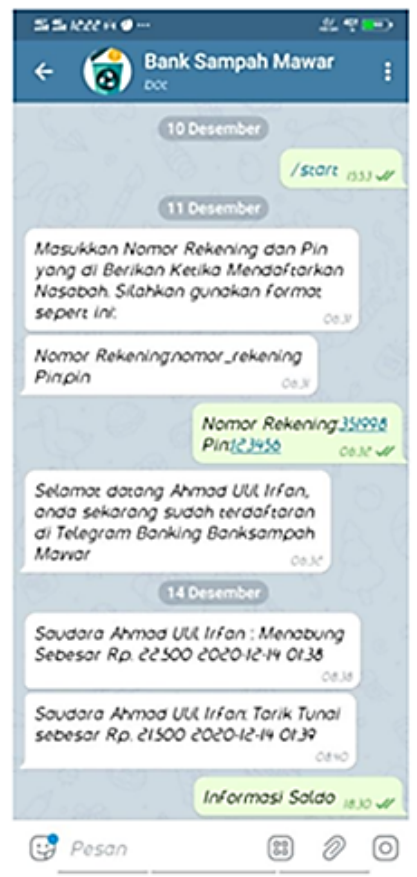

Fig. 6. Telegram bot notification page.

\subsection{Testing}

System testing uses three tests, namely black box testing, white box testing, and user acceptance test. In black box testing, a percentage of $100 \%$ is achieved and $0 \%$ fails, in white box testing results in a percentage of $100 \%$ being achieved and $0 \%$ failing with the resulting complexity of 2 , and in testing the user acceptance test produces a percentage of $98 \%$. With the test results of the system shows that the system is suitable for use (Okstania et al., 2019).

\subsection{Discussion}

In the user acceptance test, in terms of benefit, appearance and convenience, the three correspondents obtained an average percentage of 98 . With the $98 \%$ category, this means that the waste bank management information system is feasible to use.

\section{CONCLUSION}

Based on the user acceptance test, this waste bank data management information system has benefits and conveniences to manage data and use it for its users. The use of the telegram bot runs well according to user needs by providing balance information and savings flow information. System testing uses three tests, namely black box testing, white box testing, and user acceptance test. In black box testing, a percentage of $100 \%$ is achieved and $0 \%$ fails, in white box testing results in a percentage of $100 \%$ being achieved and $0 \%$ failing with the resulting complexity of 2 , and in testing the user acceptance test yields a percentage of $98 \%$. With the test results of the system shows that the system is suitable for use.

\section{REFERENCES}

Deharja, A., \& Permatasari, V. (2016). Perancangan Sistem Informasi Reminder Kegiatan Posyandu Berbasis SMS Gateway. Seminar Nasional Hasil Penelitian Dan Pengabdian Masyarakat Dana BOPTN, 69-73. https://publikasi.polije.ac.id/index.php/prosiding/arti cle/view/224/230

Destiningrum, M., \& Adrian, Q. J. (2017). Sistem Informasi Penjadwalan Dokter Berbasis Web Dengan Menggunakan Framework Codeigniter (Studi Kasus: Rumah Sakit Yukum Medical Centre). Jurnal Teknoinfo, 11(2), 30. https://doi.org/10.33365/jti.v11i2.24

Hidayat, T., \& Muttaqin, M. (2018). Pengujian Sistem Informasi Pendaftaran dan Pembayaran Wisuda Online menggunakan Black Box Testing dengan Metode Equivalence Partitioning dan Boundary Value Analysis. JUTIS, 6(1), 25-29. www.ccssenet.org/cis

Kusrini, W., Herpendi, \& Noor, M. (2019). Rancang Bangun Sistem Informasi Antar Jemput Sampah Rumah Tangga (Di Asmara). Jurnal Simetrik, 9(1), $145-151$.

Maharani, D. (2017). Perancangan Sistem Informasi Akademik Berbasis Web Pada Sekolah Islam Modern Amanah. Jurnal Manajemen Informatika 
Dan Teknik Komputer, 2(1), 27-32. https://doi.org/10.31227/osf.io/r9szc

Maulayya, F. R., Arifin, M. Z., \& Hariono, T. (2019). Rancang Bangun "Telegram Bot Api" Untuk Layanan Sistem Informasi Akademik Di Unwaha Menggunakan Metode Long Polling. Saintekbu, 11(1), 68-77. https://doi.org/10.32764/saintekbu.v11i1.360

Okstania, C., Novita, M., \& Latifah, K. (2019). Sistem Informasi Media Transparansi Program Pemberdayaan Kesejahteraan Keluarga (Pkk) Dan Event Reminder Dengan Api Telegram Berbasis Web Pada Rw 3 Kelurahan Karang Tempel Semarang. Science And Engineering National Seminar 4 (SENS 4), 4(1), 101-107.

Parianthana, P. E., Wirawan, I. M. A., \& Arthana, I. K. R. (2018). Integrasi Sistem Penjadwalan Kuliah dengan Google Calendar Serta Notifikasi Telegram. Seminar Nasional Pendidikan Teknik Informatika (SENAPATI) Ke-9, September, 117-122.

Priantoro, A., \& Rapiyanta, P. T. (2016). Perancangan Sistem Informasi Berbasis Web Pada Bank Sampah Resik Becik Sleman. Konferensi Nasional Ilmu Sosial \& Teknologi, 63-69.

Ramadhan, F. (2017). Pengembangan Media Pembelajaran Interaktif Matematika Dengan Bot Api Media Sosial Telegram Di Akademi Farmasi Surabaya. It-Edu, 2(02).

Rifai, A., \& Mustafidah, H. (2013). Rancang Bangun Sistem Informasi Nilai Mata Pelajaran Berbasis Web dan SMS Gateway ( Build-Up Lesson Score Information System Based on Web and SMS Gateway ). JUITA : Jurnal Informatika, 2(4), 239248.

Salim, Y., Atmajaya, D., Kurniati, N., \& Astuti, W. (2017). Sistem Transaksi Pengelolaan Sampah Pada Bank Sampah Unit Di Kota Makassar. Prosiding Seminar Nasional XII Rekayasa Teknologi Industri Dan Informasi 2017, 12, 290-294.

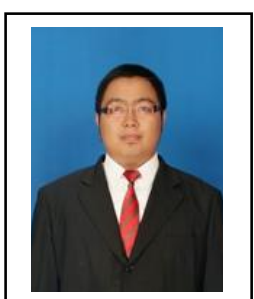

Rahmat Robi Waliyansyah obtained Bachelor Degree in Information System from Universitas Putra Indonesia-YPTK Padang in 2011, obtained Master Degree in Management Information System from Universitas Diponegoro in 2015. he has been a Lecturer with the Department of Informatics, Universitas PGRI Semarang, since 2017. His current research interests include data mining, image processing and machine learning.

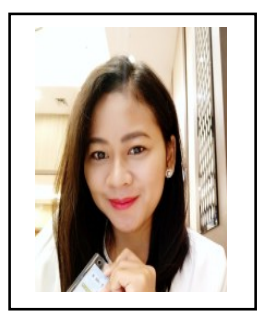

Mega Novita obtained Bachelor Degree in Mathematics from Satya Wacana Christian University in 2009, obtained double degree Master program between Magister Biology, Universitas Kristen Satya Wacana (UKSW) and Graduate School of Science and Technology, Kwansei Gakuin University (KGU) in 2011, and obtained the Doctor course in the same laboratory as her Master course. She performed a Theoretical Investigation on the Electronic Structures of Novel Red Phosphor Materials Based on Mn4+ Ion and Its Isoelectronic Ions and obtained her Doctor of Science degree (Dr.Sc) in 2015. he has been a Lecturer with the Department of Informatics, Universitas PGRI Semarang, since 2015. His current research interests include Principles ElectronicStructure Calculations of Mn4+-Doped Red Phosphors for White LED Application. 